\title{
Optimization of dietary lemon seed essential oil to enhance alfalfa silage chemical composition and in vitro degradability
}

\section{Otimização do óleo essencial de semente de limão na dieta para melhorar a composição química da silagem de alfafa e a degradabilidade in vitro}

\author{
Maghsoud Besharati ${ }^{1 *}$; Valiollah Palangii2; Masomeh Niazifar; \\ Zabihollah Nemati ${ }^{1}$
}

Highlights

Alfalfa is one of the most important sources of forage in ruminant diet which is cultivated widely around the world.

However, a significant amount of nutrient losses from alfalfa due to the mechanical treatments during drying and storage process.

Therefore, alfalfa as silage is an alternative way to prevent drying losses.

A large number of additives can improve the silage quality but processing of alfalfa silage with essential oils has not yet been widely investigated.

\begin{abstract}
Purpose of the experiment was to evaluate the effect of lemon-seed essential oils on chemical composition and in vitro degradability of alfalfa silage. Treatments were alfalfa silage with no additive (control) or treated with $60 \mathrm{ml} \mathrm{kg}^{-1}$ DM of lemon-seed (LEO60), of lemon-seed (LEO120) essential oils and equal mixed of them (M60). Whole plant alfalfa silage was ensiled for $60 \mathrm{~d}$ in triplicate laboratory scale tubes. Dry matter, organic matter, crude protein, insoluble fiber in acidic and neutral detergent, water soluble carbohydrate, $\mathrm{pH}$, were measured with 3 replicates by in vitro gas production method. Dry matter (DM) content was greater for LEO60 than control. Compared with control, neutral detergent fiber (NDF) concentration was decreased in LEO120. Addition of essential oils and their combination to the silage significantly decreased $(p<0001)$ silage $\mathrm{pH}$ compared with untreated silage interestingly increased for all the silages containing essential oil compared with untreated silage. Addition of lemon-seed essential to alfalfa silage decreased the rate of disappearance of organic matter and dry matter in all treatments compared to the control treatment. The degradability potential of alfalfa silage has increased in treatments containing lemon-seed essential oil (60

1 University of Tabriz, Ahar Faculty of Agriculture and Natural Resources, Department of Animal Science, 51666, Tabriz, Iran.E-mail:m_besharati@hotmail.com;m.niaz2@yahoo.com; znnemati@yahoo.com

2 Department of Animal Science, Agricultural Faculty, Ataturk University, 25240, Erzurum, Turkey. E-mail: valiollah. palangi12@ogr.atauni.edu.tr

* Author for correspondence
\end{abstract}

Received: Nov. 04, 2020 - Approved: Feb. 05, 2021 
$\mathrm{ml} \mathrm{kg}^{-1} \mathrm{DM}$ ) which is significantly different from the control. In general, the obtained data show the positive effect of lemon-seed essential oil on the quality of alfalfa silage and its fermentation properties.

Key words: Alfalfa silage. Degradability. Lemon-seed essential oil. Fermentation.

\section{Resumo}

Objetivo do experimento foi avaliar o efeito do óleo essencial de semente de limão na composição química e degradabilidade in vitro da silagem de alfafa. Os tratamentos foram silagem de alfafa sem aditivo (controle) ou tratada com $60 \mathrm{ml} \mathrm{kg}^{-1} \mathrm{MS}$ de óleos essenciais de caroço de limão (LEO60), de óleos essenciais de semente de limão (LEO120) e misturas iguais (M60). Silagem de planta inteira de alfafa foi ensilada por 60 dias em tubos triplicados em escala de laboratório. Matéria seca, matéria orgânica, proteína bruta, fibra insolúvel em detergente ácido e neutro, carboidrato solúvel em água, pH foram medidos com 3 repetições pelo método de produção de gás in vitro. O conteúdo de matéria seca (MS) foi maior para LEO60 do que para o controle. Em comparação com o controle, a concentração de fibra em detergente neutro (FDN) diminuiu no LEO120. A adição de óleos essenciais e sua combinação à silagem diminuiu significativamente $(p<0,0001) \circ \mathrm{pH}$ da silagem em comparação com a silagem não tratada aumentou de forma interessante para todas as silagens contendo óleo essencial em comparação com a silagem não tratada. A adição de caroço de limão essencial à silagem de alfafa diminuiu a taxa de desaparecimento da matéria orgânica e da matéria seca em todos os tratamentos em relação ao controle. O potencial de degradabilidade da silagem de alfafa aumentou nos tratamentos contendo óleo essencial de semente de limão $\left(60 \mathrm{ml} \mathrm{kg}^{-1} \mathrm{MS}\right)$, o que é significativamente diferente do controle. Em geral, os dados obtidos mostram o efeito positivo do óleo essencial de semente de limão na qualidade da silagem de alfafa e suas propriedades fermentativas.

Palavras-chave: Silagem de alfafa. Degradabilidade. Óleo essencial de semente de limão. Fermentação.

\section{Introduction}

Because of increasing public pressure to decrease the use of antimicrobials in livestock production and the regulations that ban the use of these substances in Europe, scientists and the livestock feed industry have been actively working to find alternatives to antimicrobials (Hoelzer et al. 2018; Oladokun \& Adewole, 2020). Among these alternatives, essential oils and their compounds have attracted much attention because of their antimicrobial properties that may high potential for binding to proteins (Hodaj-Çeliku et al., 2017; Abudunia et al., 2017). Therefore, these compounds modulate rumen fermentation (Joch et al., 2019; Garcia et al., 2020). Essential oils from aromatic and medicinal plants have been shown to have selective antimicrobial properties and also have a are able to affect the microbiology and protein breakdown in silage (Besharati, Palangi, Moaddab, Nemati, Pliego, \& Salem, 2020). The use of essential oils in animal feed is beneficial due to their antimicrobial properties, but determining the effect of these compounds on silage fermentation is a relatively new issue (Besharati, Palangi, Niazifar, \& Nemati, 2020). According to the arid climate and economic situation of Iran the need to use waste is quite obvious, especially since all citrus fruits are mere waste in terms of bitterness, while rich in essential oil. Methods have been developed for separating and drying seeds and commercial 
production of citrus seed essential oil has become possible previously. The composition of citrus seed essential oil (EO) has been studied in other countries and suitable methods for drying citrus seeds for essential oils and is provided for refining these essential oils (Geraci, Di Stefano, Di Martino, Schillaci, \& Schicchi, 2017; Youcef-Ettoumi, Zouambia, \& Moulai-Mostefa, 2020). Lemon belongs to the citrus family and is an evergreen tree up to 6 meters tall, it has a straight stem and barbed branches, the leaves of this shrub are alternate green or yellowish green and shiny. The fruits are small, ovate and green, yellowish green or yellow (Palangi, Taghizadeh, \& Sadeghzadeh, 2013; Aghdam et al., 2019; Rafique, Hassan, Mughal, Hassan, \& Shabbir, 2020). Lemon tree is grown in the Mediterranean and tropical regions, unlike other varieties, its lemon tree is constantly bearing fruit (Triantafyllidis, Zotos, Kosma, \& Kokkotos, 2020). Due to the lack of sufficient knowledge about the nutritional value, restrictions and the appropriate amount of citrus waste, especially the EO of sour lemon seed in the diet by farmers as well as the lack of appropriate and practical research in this field in the country, the present study seems necessary.

\section{Materials and Methods}

\section{Essential oils preparation}

The collected lemon pomace from Tabriz markets were cut and the seeds were separated, washed and dried at room temperature for a few days. About $200 \mathrm{~g}$ of milled lemon seed were immersed by maceration using $\mathrm{N}$-hexane solvent (Sayyah, Moaied, \& Kamalinejad, 2005). The essential oils were stored at $4{ }^{\circ} \mathrm{C}$ until they were used in the experiment. Aromatic compounds of lemonseed essential oil are shown in Table 1.

Table 1

Aromatic compounds in lemonseed essential oil (percentage of total compounds)

\begin{tabular}{cc}
\hline Compounds & $\%$ \\
$\mathrm{C}_{18} \mathrm{H}_{34} \mathrm{O}$ & 6.63 \\
$\mathrm{C}_{10} \mathrm{H}_{16}$ & 0.09 \\
$\mathrm{C}_{9} \mathrm{H}_{8} \mathrm{O}$ & 0.1 \\
$\mathrm{C}_{20} \mathrm{H}_{40}$ & 0.09 \\
$\mathrm{C}_{16} \mathrm{H}_{32} \mathrm{O}_{2}$ & 2.63 \\
$\mathrm{C}_{18} \mathrm{H}_{34} \mathrm{O}_{2}$ & 80.11 \\
$\mathrm{C}_{18} \mathrm{H}_{32} \mathrm{O}_{2}$ & 9.9 \\
$\mathrm{C}_{18} \mathrm{H}_{36} \mathrm{O}_{2}$ & 0.18 \\
$\mathrm{C}_{19} \mathrm{H}_{38}$ & 0.05
\end{tabular}




\section{Experimentaltreatments andsilage preparation}

The alfalfa samples were collected from a field in Tabriz province and then chopped at 3-5 cm length and ensiled in laboratory scale tubes $(3 \pm 0.25 \mathrm{~kg})$ for 60 days. Three silos for each treatment were made and stored at ambient temperature $\left(28^{\circ} \mathrm{C}\right.$ to $\left.33^{\circ} \mathrm{C}\right)$. The minisilos (10 cm diameter and $70 \mathrm{~cm}$ height) were then sealed and stored at room temperature for 60 days. After 60 days of ensiling, all silos were opened and were used for the analysis of fermentation quality and aerobic stability test. So the treatments were: without essential oil (control), with essential oil $60 \mathrm{mg} \mathrm{kg}^{-1} \mathrm{DM}$ (LEO60) and $120 \mathrm{mg} \mathrm{kg}^{-1}$ DM (LEO120). Each treatment was provided in triplicate tubes. All essential oils were dissolved in aqueous ethanol (Chaves, 2012) and sprayed onto the chopped forages. The same amount of the ethanol was also added to the control.

\section{Chemical analysis}

Chemical compositions of the silage samplesweremeasuredbeforeandimmediately after the opening. After the opening of silages, the $\mathrm{pH}$, dry matter (DM) (method ID 942.05) and soluble carbohydrate (WSC) of the samples were determined. DM content of the silages was determined by oven drying of lucerne samples $\left(65^{\circ} \mathrm{C}\right.$ for 48 h). DM, ash (CA), ether extract (EE) and crude protein (CP) (CP, method ID 984.13) contents were determined by the procedures given by Association of Offical Analytic Chemists [AOAC] (2002). The neutral detergent fiber (NDF) and acid detergent fiber (ADF) concentrations were determined according to Van Soest, Robertson and Lewis. (1991) procedures without the use of amylase and sodium sulphite. NDF was analyzed without amylase and contains the ash. Aqueous extract was prepared from ensiled samples by mixing $20 \mathrm{~g}$ of forage with $180 \mathrm{ml}$ of deionized water and homogenizing this mix for $1 \mathrm{~min}$. Then, silage $\mathrm{pH}$ was determined using a portable $\mathrm{pH}$ meter. Ammonia- $\mathrm{N}\left(\mathrm{NH}_{3}-\mathrm{N}\right)$ concentration of acidified silage extracts were determined using Kjeldahl method. Phenol sulfuric acid method was used to measure WSC contents (Dubios, Giles, Hamilton, Ronerts, \& Smith, 1956). The distillation method described by Markham (1942) was used to measure total volatile fatty acids (tVFA) in silages. One $\mathrm{ml}$ of $25 \%$ meta-phosphoric acid (v/w) was added to $5 \mathrm{ml}$ of filtered extract to calculate the volatile fatty acids. For the determination of lactic acid (LA) contents, the method of Borshchevskaya et al. (2016) was used.

\section{In vitro degradability}

Ruminal fluid was taken from two sheep fitted with cannulae and transferred immediately to laboratory. Approximately 300 $\mathrm{mg}$ of samples added to serum bottles. The 20 $\mathrm{mL}$ of Buffered rumen fluid with McDougall's buffer was pipetted into each serum bottle. The degradability was recorded after 2, 4, 8, $12,24 \mathrm{~h}$ of incubation. Seven replicates with 3 blanks were considered for each treatment. The volumes of fermentation were corrected for the blank incubation, and degradability values are expressed as $\mathrm{mL} \mathrm{g}^{-1}$ of DM. Rate and extent of degradability was determined for each treatment by fitting data to the nonlinear function $Y=a+b(1-e-c t)$, where $y$ is the volume of gas produced at time $t, a+b$ the fermentation of soluble and insoluble fraction ( $\mathrm{mL} \mathrm{g}^{-1}$ of DM), and $\mathrm{c}$ the constant fractional rate of fermentation.

$$
\begin{gathered}
P D=a+b \\
E D=a+[b c /(c+k)]
\end{gathered}
$$


Where ' $a$ ', ' $b$ ' and ' $c$ ' are the constants as described earlier in the different mathematical models above and ' $k$ ' is the rumen fractional outflow rate (Palangi, Macit, \& Bayat, 2020; Palangi, \& Besharati, 2020).

\section{In vitro degradability}

Data obtained from chemical composition and gas production were subjected to analysis of variance as a completely randomized design by the GLM procedure of SAS, and were analyzed according to statistical model:

$$
Y i j=\mu+T i+e i j
$$

Where, Yij is the dependent variable, $\mu$ is overall mean, $\mathrm{Ti}$ is effect of treatment and eij is random error. The significance of differences among treatments was tested using Duncan test. Differences were declared as significant at $p \leq 0.05$.

\section{Results}

\section{Chemical composition}

Chemical composition, $\mathrm{pH}$ of the experimental silages is shown in figure 1 . Higher DM content was observed in LEO60 and LEO120 compared with the control $(p<0.001)$, which could be attributed to the limitation of development of special groups of microorganism and therefore smaller loss of nutrients (Besharati \& Niazifar, 2020). Relative to the control, CP concentration was increased with other treatments supplemented with essential oils $(P<0.001)$. The LEO60 and LEO120 silages had lower NDF concentration compared with control $(p<0.001)$. The ADF content decreased in all treatments compared with control silage. addition of essential oils to alfalfa silage resulted in decreasing $\mathrm{pH}$ value $(p<0.001)$ compared with control.

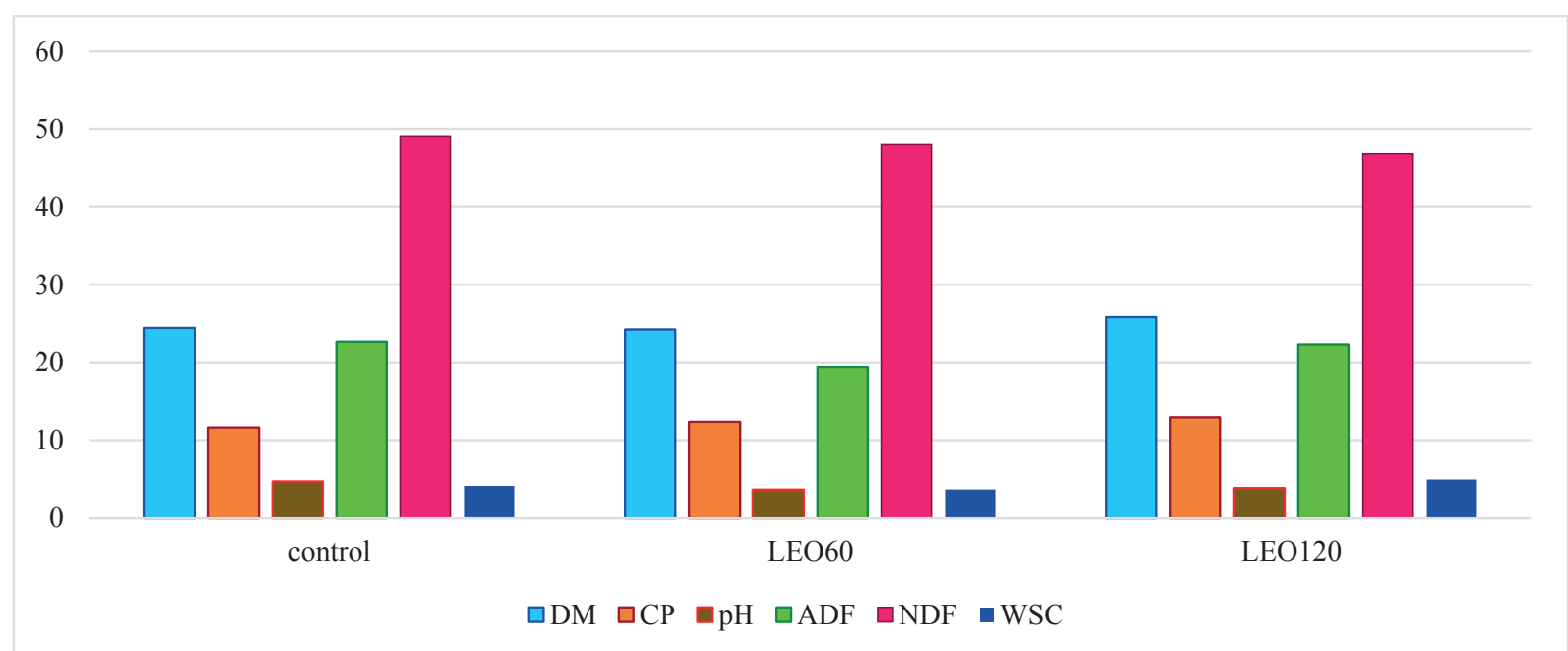

Figure 1. Effect of lemonseed Essential Oil on Chemical Properties of Alfalfa Silage after $60 \mathrm{~d}$ of Silage (\%DM)

Treatment: control: Alfalfa silage without additives, LEO60: alfalfa silage with $60 \mathrm{ml}$ lemonseed

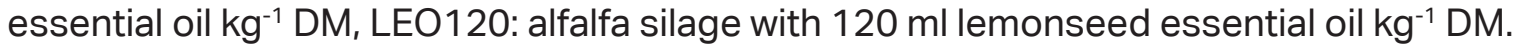

Chemical composition2: DM, dry matter; $\mathrm{CP}$, crude protein; $\mathrm{CA}$, crude ash; NDF, neutral detergent fiber; ADF, acid detergent fiber, WSC: water soluble carbohydrate. 
In vitro degradability

Results of degradability values and degradability parameters are shown in Table 2. Addition of lemonseed essential oil to alfalfa silage increased the rate of degradability of organic matter and dry matter in all treatments compared to the control ( $p<0.05$ ). After 24 hours of incubation, the treatment LEO60 had the highest and the treatment control had the lowest fermentation of organic matter ( $p$ $<0.05)$. According to the presented results, in 2 hours after incubation, the highest rate of degradability of crude protein was related to the treatment LEO60 and the lowest rate of degradability of crude protein is related to the control. In 24 hours after incubation, the highest rate of fermentation was related to the control, which was significantly different from other treatments. The concentration of essential oils in plants is affected by factors such as species, subspecies, geographical location, harvest time of the plant and the part used for essential oil collection. In addition, factors such as light and heat and moisture stress also affect their concentration in the plant.

\section{Table 2}

The effect of different levels of Lemonseed essential oil on fermentation properties of alfalfa silage (ml/g DM)

\begin{tabular}{|c|c|c|c|c|c|}
\hline \multirow[t]{2}{*}{ Treatments $^{1}$} & \multicolumn{5}{|c|}{ Incubation times (h) } \\
\hline & 2 & 4 & 8 & 12 & 24 \\
\hline \multicolumn{6}{|l|}{ DM } \\
\hline control & $24.93^{c}$ & $34.99^{c}$ & $46.64^{c}$ & $51.24^{c}$ & $61.88^{c}$ \\
\hline LEO60 & $40.11^{a}$ & $49.44^{a}$ & $53.94^{a}$ & $57.97^{a}$ & $65.82^{a}$ \\
\hline LE0120 & $28.67^{b}$ & $40.22^{b}$ & $50.22^{b}$ & $56.70^{\mathrm{ab}}$ & $63.16^{b}$ \\
\hline SEM & 0.935 & 1.155 & 0.608 & 0.622 & 0.289 \\
\hline$p$-value & $<.0001$ & $<.0001$ & $<.0001$ & $<.0001$ & $<.0001$ \\
\hline \multicolumn{6}{|l|}{$O M$} \\
\hline control & $27.67^{\mathrm{ab}}$ & $27.67^{c}$ & $38.33^{a b}$ & $52.52^{b}$ & $61.84^{c}$ \\
\hline LEO60 & $40.11^{a}$ & $49.45^{a}$ & $53.95^{\mathrm{a}}$ & $57.98^{a}$ & $65.82 a$ \\
\hline LEO120 & $28.67^{b}$ & $40.23^{b}$ & $50.23^{b}$ & $56.70^{\mathrm{ab}}$ & $63.15 b$ \\
\hline SEM & 0.056 & 0.138 & 0.049 & 0.093 & 0.064 \\
\hline$p$-value & $<.0001$ & 0.0045 & $<.0001$ & 0.0003 & $<.0001$ \\
\hline \multicolumn{6}{|l|}{$\mathrm{CP}$} \\
\hline control & $17.59^{a}$ & $23.16^{b}$ & $34.44^{\mathrm{a}}$ & $45.32^{\mathrm{a}}$ & $56.52^{\mathrm{a}}$ \\
\hline LEO60 & $14.05^{\mathrm{c}}$ & $24.46^{a}$ & $30.30^{b}$ & $33.05^{\mathrm{c}}$ & $45.54^{b}$ \\
\hline LEO120 & $15.36^{b}$ & $23.54^{\mathrm{ab}}$ & $27.17^{c}$ & $35.97^{b}$ & $40.18^{c}$ \\
\hline SEM & 0.456 & 0.583 & 2.402 & 1.386 & 0.769 \\
\hline$p$-value & $<.0001$ & $<.0001$ & 0.007 & $<.0001$ & $<.0001$ \\
\hline
\end{tabular}


contuation...

\begin{tabular}{|c|c|c|c|c|c|}
\hline NDF & & & & & \\
\hline control & $24.32^{a}$ & $42.58^{c}$ & $31.57^{b}$ & $36.767^{b}$ & $47.43^{a b}$ \\
\hline LEO60 & $23.11^{\mathrm{b}}$ & $45.60^{b}$ & $32.13^{a}$ & $37.43^{a}$ & $48.03^{a}$ \\
\hline LEO120 & $20.93^{c}$ & $51.40^{a}$ & $28.83^{c}$ & $34.17^{c}$ & $44.84^{b}$ \\
\hline SEM & 0.825 & 1.151 & 1.187 & 1.380 & 1.437 \\
\hline$p$-value & 0.0387 & 0.014 & 0.040 & 0.0246 & 0.0312 \\
\hline
\end{tabular}

Treatment ${ }^{1}$-control: Alfalfa silage without additives, LEO60: alfalfa silage with $60 \mathrm{ml}$ cinnamon essential oil $\mathrm{kg}^{-1} \mathrm{DM}$, LEO120: alfalfa silage with $120 \mathrm{ml}$ cinnamon essential oil kg-1 DM. Means within same column with different superscripts differ $(\mathrm{P}<0.05)$.

$\mathrm{DM}$, dry matter; $\mathrm{CP}$, crude protein; NDF, neutral detergent fiber; $A D F$, acid detergent fiber.

\section{Degradation parameters}

The fermentation properties of dry matter, crude protein, neutral detergentinsoluble fibers and organic matter of alfalfa silage are presented in Table 3. The results show that LEO60 significantly increases the effective degradability (ED) at a passage rate of $2 \%$ per hour, which also increases the soluble fraction of dry matter (a). The degradability potential (PD) of alfalfa silage in the LEO120 increased, which is statistically significant with the control $(p<0.05)$. Decreased degradability of insoluble part (b) of alfalfa silage by adding LEO60, which was significant compared to the control. Increasing or decreasing the degradability of the insoluble part depends on the dose used at the silage level. Constant dry matter degradability rate, LEO60 was significantly different from control and was numerically higher than them. According to the reported results, the organic matter solution (a) was significantly different, which was statistically significant with the control treatment. LEO60 treatment significantly increased the soluble fraction of organic matter compared to the control. The effective digestibility of organic matter (ED) at a passage rate of $2 \%$ per hour was the highest for LEO60. According to the reported results, the rate of degradability of the rapidly decomposing part (a) of crude protein, LEO120 has a significantly increase with the control. The results of this experiment showed that the addition of essential oils to alfalfa silage caused a significant Decrease in insoluble fraction (b) of crude protein $(p<0.05)$. In terms of effective degradability (ED) of crude alfalfa silage protein, the highest amount is related to the control and the lowest amount of ED is related to LEO60 at a passing rate of $2 \%$ per hour, which shows a significant decrease compared to all treatments $(p<0.05)$. 
Table 3

The effect of different levels of cinnamon essential oil on fermentation properties parameters of alfalfa silage

\begin{tabular}{|c|c|c|c|c|c|c|c|c|}
\hline \multirow[t]{2}{*}{ Treatments $^{1}$} & \multicolumn{8}{|c|}{ Items } \\
\hline & a & $b$ & $c$ & $P D$ & $E D$ & $K(0.01)$ & $K(0.05)$ & $K(0.08)$ \\
\hline \multicolumn{9}{|l|}{ DM } \\
\hline Control & $14.73^{b}$ & $49.01^{a}$ & $0.125^{b}$ & $63.75^{b}$ & $56.89^{c}$ & $60.13^{c}$ & $50.46^{c}$ & $44.63^{c}$ \\
\hline LEO60 & $34.97^{a}$ & $32.71^{c}$ & $0.112^{c}$ & $67.68^{a}$ & $59.45^{\mathrm{a}}$ & $64.97^{a}$ & $57.54^{a}$ & $54.03^{a}$ \\
\hline LEO120 & $15.84^{\mathrm{ab}}$ & $47.94^{b}$ & $0.164^{a}$ & $63.77^{b}$ & $57.23^{b}$ & $61^{\mathrm{b}}$ & $52.56^{b}$ & $48.07^{b}$ \\
\hline Sem & 1.994 & 1.917 & 0.010 & 0.66 & 1.055 & 0.537 & 0.616 & 0.331 \\
\hline$P$-value & 0.0006 & $<.0001$ & $<.0001$ & 0.008 & $<.0001$ & 0.001 & $<.0001$ & $<.0001$ \\
\hline \multicolumn{9}{|l|}{$O M$} \\
\hline Control & $48.53^{b}$ & $16.25^{a}$ & $0.046^{c}$ & $64.78^{b}$ & $63.209^{a}$ & $66.1^{\mathrm{a}}$ & $63^{b}$ & $61.9^{c}$ \\
\hline LEO60 & $48.48^{b}$ & $15.12^{b}$ & $0.177^{a}$ & $63.0^{\circ}$ & $63.18^{\mathrm{ab}}$ & $63.3^{c}$ & $62.5^{c}$ & $62^{\mathrm{ab}}$ \\
\hline LEO120 & $49.82^{\mathrm{a}}$ & $15.91^{\mathrm{ab}}$ & $0.0772^{b}$ & $65.73^{a}$ & $62.70^{c}$ & $65.1^{\mathrm{ab}}$ & $63.4^{a}$ & $62.7^{a}$ \\
\hline Sem & 0.661 & 0.761 & 0.0300 & 0.596 & 0.681 & 0.382 & 0.123 & 0.0745 \\
\hline$P$-value & 0.014 & 0.019 & 0.018 & 0.004 & 0.051 & $<.0001$ & $<.0001$ & $<.0001$ \\
\hline \multicolumn{9}{|l|}{$C P$} \\
\hline Control & $7.83^{b}$ & $54.70^{\mathrm{a}}$ & $0.090^{c}$ & $62.53^{a}$ & $56.87^{a}$ & $42.67^{a}$ & $35.50^{a}$ & $46.30^{a}$ \\
\hline LEO60 & $6.39^{c}$ & $34.46^{a b}$ & $0.155^{a}$ & $40.84^{c}$ & $38.63^{c}$ & $32.13^{c}$ & $24.13^{c}$ & $33.18^{c}$ \\
\hline LEO120 & $8.55^{a}$ & $37.54^{b}$ & $0.119^{b}$ & $46.09^{b}$ & $42.80^{b}$ & $34.10^{b}$ & $30.06^{b}$ & $33.67^{\mathrm{ab}}$ \\
\hline Sem & 0.614 & 3.186 & 0.0204 & 3.359 & 2.574 & 1.087 & 0.701 & 1.246 \\
\hline$P$-value & 0.0128 & 0.008 & 0.016 & $<.0001$ & 0.005 & $<.0001$ & $<.0001$ & $<.0001$ \\
\hline \multicolumn{9}{|l|}{ NDF } \\
\hline Control & $22.71^{a}$ & $42.58^{b}$ & $0.036^{b}$ & $65.30^{\mathrm{b}}$ & 56.03 & $40.43^{a}$ & $35.93^{a}$ & $40.48^{a}$ \\
\hline LEO60 & $19.43^{b}$ & $45.60^{c}$ & $0.042^{a}$ & $65.03^{c}$ & 56.06 & $40.03^{b}$ & $34.96^{b}$ & $40.05^{\mathrm{ab}}$ \\
\hline LEO120 & $17.89^{\circ}$ & $51.40^{a}$ & $0.031^{c}$ & $69.29^{a}$ & 56.67 & $37.56^{c}$ & $32.26^{c}$ & $37.57^{c}$ \\
\hline Sem & 0.864 & 3.178 & 0.0032 & 2.808 & 1.787 & 1.191 & 1.176 & 1.195 \\
\hline P-value & 0.0574 & 0.017 & $<.0001$ & 0.023 & 0.0612 & 0.024 & 0.015 & 0.025 \\
\hline
\end{tabular}

Treatment ${ }^{1}$-control: Alfalfa silage without additives, LEO60: alfalfa silage with $60 \mathrm{ml}$ lemon seed essential oil kg-1 DM, LEO120: alfalfa silage with $120 \mathrm{ml}$ lemon seed essential oil kg-1 DM. Means within same column with different superscripts differ $(P<0.05)$.

$\mathrm{DM}$, dry matter; $\mathrm{CP}$, crude protein; NDF, neutral detergent fiber; $A D F$, acid detergent fiber.

\section{Ruminal metabolites}

The effect of adding essential oils in this study on the concentration of total volatile fatty acids and ammonia nitrogen and $\mathrm{pH}$ alfalfa silage in 24 hours after incubation is shown in Table 4. After 24 hours of incubation, the amount of ammonia nitrogen in LEO60 increased and the LEO120 decreased ( $p$ $<0.05$ ). The results show that the addition of LEO60 caused a significant increase in total volatile fatty acid ( $p<0.05$ ). The lowest amount of volatile fatty acids was related to the treatment LEO120. However, decreased 
ruminal ammonia nitrogen concentration along with decreased total volatile fatty acid concentration, indicates that fermentation in the diet as a whole has decreased The results of $\mathrm{pH}$ changes in 24 hours after incubation show that the $\mathrm{pH}$ of all treatments increased slightly. The highest significant increase was related to the treatment LEO120 compared to the control $(p<0.05)$.

\section{Table 4}

Efects of cinnamon essential oil on volatile fatty acids, ammonia nitrogen and $\mathrm{pH}$ of pomegranate seed in $24 \mathrm{~h}$ of incubation

\begin{tabular}{|c|c|c|c|c|c|}
\hline \multirow[t]{2}{*}{ Treatments $^{1}$} & \multicolumn{5}{|c|}{ Incubation times (h) } \\
\hline & 2 & 4 & 8 & 12 & 24 \\
\hline \multicolumn{6}{|l|}{ DM } \\
\hline control & $6.93^{a}$ & $6.83^{a}$ & $6.77^{\mathrm{ab}}$ & $6.603^{b}$ & $6.49^{c}$ \\
\hline LEO60 & $6.86^{b}$ & $6.82^{\mathrm{ab}}$ & $6.78^{a}$ & $6.666^{\mathrm{a}}$ & $6.54^{b}$ \\
\hline LEO120 & $6.84^{c}$ & $6.81^{\mathrm{b}}$ & $6.71^{\mathrm{b}}$ & $6.593^{c}$ & $6.55^{a}$ \\
\hline SEM & 0.0175 & 0.013 & 0.009 & 0.0292 & 0.0211 \\
\hline$p$-value & 0.0046 & 0.0058 & 0.004 & 0.0236 & 0.0021 \\
\hline \multicolumn{6}{|l|}{ NH3-N } \\
\hline control & $84^{\mathrm{a}}$ & $100.33^{a}$ & $112^{\mathrm{a}}$ & $135.33^{a}$ & $142.33^{b}$ \\
\hline LEO60 & $77^{c}$ & $81.67^{c}$ & $91^{c}$ & $107.33^{c}$ & $170.33^{a}$ \\
\hline LEO120 & $82^{b}$ & $95.67^{b}$ & $105^{b}$ & $116.67^{b}$ & $133^{c}$ \\
\hline SEM & 4.04 & 2.33 & 4.41 & 4.145 & 4.467 \\
\hline$p$-value & 0.004 & 0.003 & 0.027 & 0.007 & 0.0026 \\
\hline \multicolumn{6}{|l|}{ VFA } \\
\hline control & $61^{b}$ & $46.33^{b}$ & $40.33^{b}$ & $35^{b}$ & $24.67^{b}$ \\
\hline LEO60 & $91.67^{a}$ & $68.33^{a}$ & $61^{a}$ & $54.33^{a}$ & $49^{a}$ \\
\hline LEO120 & $33.33^{c}$ & $29^{c}$ & $23.33^{c}$ & $13.66^{c}$ & $11.33^{c}$ \\
\hline SEM & 0.922 & 2.325 & 0.922 & 1.401 & 1.551 \\
\hline$p$-value & $<.0001$ & $<.0001$ & $<.0001$ & $<.0001$ & $<.0001$ \\
\hline
\end{tabular}

Treatment ${ }^{1}$-control: Alfalfa silage without additives, C60: alfalfa silage with $60 \mathrm{ml}$ cinnamon essential oil kg-1 DM , C120: alfalfa silage with $120 \mathrm{ml}$ cinnamon essential oil kg-1 DM. Means within same column with different superscripts differ $(P<0.05)$. 


\section{Discussion}

\section{Chemical composition}

Sheikh and Jain. (2016) estimated the average dry matter, crude protein, ether extract, crude ash and neutral detergentinsoluble fibers in alfalfa forage19.18, 16.6, 1.47, 11.12, 36.15, respectively. Gozalpur, Besharati, Nemati and Abdi. (2017) expressed the amount of dry matter, crude protein, ether extract, ash and neutral detergent-insoluble fibers in alfalfa 35, 14.70, 6.1, 9.8, 41.86, respectively, which differs from the findings of the present experiment, these differences can be due to differences in environmental conditions, type of cultivar and agricultural management.

Vasconcelos, Croda and Simionatto. (2018) reported that essential oils have the potential to coagulate some cell wall constituents by denaturing proteins. In agreement with our result, one experiment also reported that essential oils had inhibitory effect on growth of clostridia (Vergis, Gokulakrishnan, Agarwal, \& Kumar, 2015). From the results of this experiment it can be concluded, probably because essential oils inhibit the microorganisms that are responsible for spoilage in the silo, they have lowered the $\mathrm{pH}$. On the other hand, lowering the $\mathrm{pH}$ reduces the action of proteolysis and plant enzymes or respiratory enzymes, which prevents the degradation of silage and the conversion of protein to non-protein nitrogen. The loss of ADF in supplemented silages could be related to more acidic condition in these treatments leading to hydrolyses of cell wall during of fermentation. Lower $\mathrm{pH}$ value in treated silage could be resulted of increasing in activity of Lactobacillus bacteria, as greater amounts of lactic acid can lead to decreased silage $\mathrm{pH}$ (Borreani, Tabacco, Schmidt, Holmes, \& Muck, 2018). Some in vitro experiments have reported the effect of essential oils on the growth and development of acetic acid bacteria (Júnior, Capucho, Garcia, Del Valle, Campana, Zilio, Azevedo, \& Morais, 2020). Experimental results show the amount of soluble carbohydrates in alfalfa silage varies significantly depending on the amount, level and type of essential oils. So that the highest amount is related to the essential oil of lemon seed at the level of 120 and the lowest amount is related to the essential oil of lemon seed at the level of 60 ( $p<0.05)$. The effect of silage on the concentration of forage carbohydrates is complex and concentration of insoluble fibers in neutral detergent in addition to hydrolysis, due to other effective factors such as plant respiration, the effluent is removed and the fermentation changes.

\section{In vitro degradability}

Effects of essential oils on rumen microbial populations are dose-dependent (Macheboeuf, Morgavi, Papon, Mousset, \& Arturo-Schaan, 2008). The results of this experiment are in agreement with the findings of Hodjatpanah-Montazeri, Danesh Mesgaran, \& Vakili. (2016) and Chavez (2012). Moselhy, Borba, \& Borba. (2015) used pulp lemon essential oils as an additive to alter the fermentation characteristics of lucerne silage in ruminants and showed that thyme essential oil reduced the amount of degradability values in comparison with control silage. Elcoso, Zweifel and Bach. (2019) reported that bacterial inoculation increased the digestibility of dry matter, organic matter, insoluble fibers in neutral detergents, and insoluble fibers in acidic 
detergents. In another experiment, processing of alfalfa silage with thyme essential oils resulted in decreasing of in vitro Degradation (Pour, Naserian, Vakili, \& Tahmasbi, 2017). In the experiment of Hodjatpanah-Montazeri, Danesh Mesgaran, \& Vakili. (2016) by examining the essential oils of mint, oregano, thyme, cumin and cinnamon to change silage fermentation and in-vitro gas production showed that the degradability of essential oil treatments in 24 hours of incubation increased significantly compared to the control.

\section{Degradation parameters}

Moselhy et al. (2015) stated that the addition of essential oils has an effect on functionalityno digestion bylaboratorymethod. In general, it can be concluded that citrus essential oils have the ability to alter ruminal fermentation processes, however, more tests are needed to determine the appropriate dose of essential oil for different species essential oils can alter the binding and colonization of ruminal microbes relative to plant materials entering the rumen and are likely to affect the segregation of insoluble protein sources as opposed to soluble protein sources (Moselhy et al., 2015). Due to the low amount of soluble carbohydrates, alfalfa makes the fermentable substrate as a limiting factor in the process of changing silage compositions. In this case, the addition of compounds such as essential oils with cell wall digestion provides the amount of substrate available for fermentation (Besharati, Shafipour, \& Nemati, 2019). High cell wall digestibility has a positive effect on dry matter intake, while cell wall concentration has a negative correlation with the amount of feed cell wall (Duodu, Taylor, Belton, \& Hamaker, 2003). Lemus, Bonilla, Plasencia, \& Ly. (2012) investigated the effect of plant essential oils on ruminal microbial fermentation and feed utilization in vitro. The results showed that the effect of essential oil composition on ruminal microbial activity varied depending on the concentrations. Foskolos, Cavini, Ferret, \& Calsamiglia. (2016) stated that the upper cell wall reduces food intake by filling the gastrointestinal tract. Kouazounde et al. (2015) reported that the addition of Citrus, Ocimum reduced the digestibility of crude fiber in vitro and this is probably due to the fact that they have used their active ingredients instead of essential oils.

\section{Ruminal metabolites}

Busquet, Calsamiglia, Ferret, Carro and Kamel. (2005) stated that the essential oils of cinnamon, cloves, oregano and green tea as well as garlic oil, cinnamaldehyde, caracrol and eugenol increased the $\mathrm{pH}$ of the abdomen during 24 hours of incubation. In studies (Kolling, Stivanin, Gabbi, Machado, Ferreira, Campos, \& Fischer, 2018; Foskolos, Cavini, Ferret, \& Calsamiglia, 2016), an increase in $\mathrm{pH}$ was associated with a decrease in the concentration of total volatile fatty acids, which indicates a decrease in the fermentability of the diet due to the antimicrobial activity of phenolic compounds. In general, the differences between the results of the present study and other studies can be related to differences in the type, dose and chemical composition of the essential oil used, the composition of the basic diet and test conditions (in vivo versus in vitro, the duration of the test). 


\section{Conclusions}

Alfalfa is one of the most important sources of forage in ruminant diet which is cultivated widely around the world. However, a significant amount of nutrient losses from alfalfa due to the mechanical treatments during drying and storage process. Therefore, feeding alfalfa as silage is an alternative way to prevent drying losses. A large number of additives can improve the silage quality but processing of alfalfa silage with essential oils has not yet been widely investigated.

\section{Authors' contributions}

$\mathrm{MB}, \mathrm{MN}$ and $\mathrm{ZN}$ collected the data for this study, conducted the statistical analyses, MB developed the original hypotheses and designed the experiments, VP collaborated in interpreting the results and finalized the manuscript. Both authors have read and approved the finalized manuscript.

\section{Conflict of Interest Declaration}

The authors declare that they have no known competing financial interests or personal relationship that could have appeared to influence the work reported in this paper.

\section{References}

Abudunia, A. M., Hafidi, H., Algabr, M., Akachar, J., Almahbashi, H., Ramli, Y., \& Khedid, K. (2017). Evaluation of essential oils for antimicrobial activity from some Moroccan aromatic plants medicinal. Journal of Materials and Environmental Science, 8(12), 4240-4245. Recovered from http:// www. jmaterenvironsci.com/
Adesogan, A. T., Krueger, N., Salawu, M. B., Dean, D. B., \& Staples, C. R. (2004). The influence of treatment with dual purpose bacterial inoculants or soluble carbohydrates on the fermentation and aerobic stability of bermudagrass. Journal of Dairy Science, 87(10), 3407-3416. doi: 10.3168/jds. S0022-0302(04)73476-1

Aghdam, M. S., Luo, Z., Jannatizadeh, A., SheikhAssadi, M., Sharafi, Y., Farmani, B., \& Razavi, F. (2019). Employing exogenous melatonin applying confers chilling tolerance in tomato fruits by upregulating ZAT2/6/12 giving rise to promoting endogenous polyamines, proline, and nitric oxide accumulation by triggering arginine pathway activity. Food Chemistry, 275(1), 549-556. doi: 10.1016/j.foodchem.2018. 09.157

Association of Offical Analytic Chemists (2002). Official method of Analytic (vol. 1, 17nd ed.). Arlington, VA: AOAC.

Benchaar, C., McAllister, T. A., Petit, H. V., \& Chouinard, P. Y. (2014). Whole flax seed and flax oil supplementation of dairy cows fed high-forage or high-concentrate diets: effects on digestion, ruminal fermentation characteristics, protozoal populations and milk fatty acid profile. Animal Feed Science Technology, 198, 117-29. doi: 10.1016/j. anifeedsci.2014.10.003

Besharati, M., \& Niazifar, M. (2020). The effect of lemon seed essential oil on composition, chemical characteristics, and gas production parameters of alfalfa silage. Journal of Animal Science, 30(1), 93-104. doi: 10.22034/AS.2020.11018

Besharati, M., Palangi, V., Moaddab, M., Nemati, Z., Pliego, A. B., \& Salem, A. Z. (2020). Influence of cinnamon essential oil and 
monensin on ruminal biogas kinetics of waste pomegranate seeds as a biofriendly agriculture environment. Waste and Biomass Valorization, (in press). doi: 10.1007/s12649-020-01167-2

Besharati, M., Palangi, V., Niazifar, M., \& Nemati, Z. (2020). Comparison study of flaxseed, cinnamon and lemon seed essential oils additives on quality and fermentation characteristics of lucerne silage. Acta Agriculturae Slovenica, 2(424), 115. doi: 10.14720/aas.2020.115.2.1483

Besharati, M., Shafipour, N., \& Nemati, Z. (2019). Effect of supplementation of alfalfa silage with Lactobacillus Buchneri additive, orange pulp and molasses on dry matter, crude protein and organic matter degradability by nylon bags. Research Animal Production, 10(23), 45-52. doi: 10.29252/rap. 10.23.45

Bodas, R., Prieto, N., García-González, R., Andrés, S., Giráldez, F. J., \& López, S. (2012). Manipulation of rumen fermentation and methane production with plant secondary metabolites. Animal Feed Science Technology, 176(1-4), 78-93. doi: 10.1016/j.anifeedsci.2012.07.010

Borchers, R. (1965). Proteolytic activity of rumen fluid in vitro. Journal of Animal Science, 24(4), 1033-1038. doi: 10.2527/ jas 1965.2441033x

Borreani, G., Tabacco, E., Schmidt, R. J., Holmes, B. J., \& Muck, R. E. (2018). Silage review: factors affecting dry matter and quality losses in silages. Journal of Dairy Science, 101(5), 3952-3979. doi: 10. 3168/ jds.2017-13837

Borshchevskaya, L. N., Gordeeva, T. L., Kalinina, A. N., \& Sineokii, S. P. (2016).
Spectrophotometric determination of lactic acid. Journal of Analytical Chemistry, 71(8), 755-758. doi: 10.1134/S1061934 816080037

Busquet, M., Calsamiglia, S., Ferret, A., Carro, M. D., \& Kamel, C. (2005). Effect of garlic oil and four of its compounds on rumen microbial fermentation. Journal of Dairy Science, 88(12), 4393-4404. doi: 10. 3168/jds.S0022-0302(05)73126-X

Chaves, A. V. (2012). Effects of cinnamon leaf, oregano and sweet orange essential oils on fermentation and aerobic stability of barley silage. Journal of Science Food and Agriculture, 92(4), 906-915. doi: 10. 1002/ jsfa.4669

Dubios, A., Giles, M. K. A., Hamilton, J. K., Ronerts, P. A., \& Smith, F. (1956). Colorimetric method for determination of sugars and related substances. Analytical Chemistry, 28(30), 350-356. doi: 10.1021/ ac $60111 \mathrm{a} 017$

Dunière, L., Sindou, J., Chaucheyras-Durand, F., Chevallier, I., \& Thévenot-Sergentet, D. (2013). Silage processing and strategies to prevent persistence of undesirable microorganisms. Animal Feed Science and Technology, 182(1-4), 1-15. doi: 10.1016/j. anifeedsci.2013.04.006

Duodu, K. G., Taylor, J. R. N., Belton, P. S., \& Hamaker, B. R. (2003). Factors affecting sorghum protein digestibility. Journal of Cereal Science, 38(2), 117-31. doi: 10.1016/S0733-5210(03)00016-X

Elcoso, G., Zweifel, B., \& Bach, A. (2019). Effects of a blend of essential oils on milk yield and feed efficiency of lactating dairy cows. Applied Animal Science, 35(3), 304311. doi: 10.15232/aas.2018-018 25 
Foskolos, A., Cavini, S., Ferret, A., \& Calsamiglia, S. (2016). Effects of essential oil compounds addition on ryegrass silage protein degradation. Canadian Journal of AnimalScience, 96(2), 100-3. doi: 10.1139/ cjas-2015-0025

Garcia, F., Colombatto, D., Brunetti, M. A., Martínez, M. J., Moreno, M. V., Scorcione Turcato, M., \& Martínez Ferrer, J. (2020). The reduction of methane production in the in vitro ruminal fermentation of different substrates is linked with the chemical composition of the essential oil. Animals, 10(5), 786. doi: 10.3390/ani10050786

Geraci, A., Di Stefano, V., Di Martino, E., Schillaci, D., \& Schicchi, R. (2017). Essential oil components of orange peels and antimicrobial activity. Natural Product Research, 31(6), 653-659. doi: 10.1080/ 14786419.2016 .1219860

Gozalpur, V., Besharati, M., Nemati, Z., \& Abdi, E. (2017). Effect of commercial essential oil (ESSENTIAL) on the characteristics of silage alfalfa with apple pulp. Proceeding of the International and National Conference on Organic vs. Conventional Agriculture, Ardabil, Iran, 1, 5. Recovered from https:// civilica.com/doc/932840

Hodaj-Çeliku, E., Tsiftsoglou, O., Shuka, L., Abazi, S., Hadjipavlou-Litina, D., \& Lazari, D. (2017). Antioxidant activity and chemical composition of essential oils of some aromatic and medicinal plants from Albania. Natural Product Communications, 12(5), 785-790. doi: $10.1177 / 1934578 \times 1701200525$

Hodjatpanah-Montazeri, M., Danesh Mesgaran, M., \& Vakili, A. (2016). Effect of Essential Oils of Various Plants as Microbial Modifier to Alter Corn Silage Fermentation and in vitro Methane Production. Iranian Journal of Applied Animal Science, 6(2), 269-276. Recovered from http://ijas. iaurasht.ac.ir/ article_522780.html

Hoelzer, K., Bielke, L., Blake, D. P., Cox, E., Cutting, S. M., Devriendt, B., \& Metzner, M. (2018). Vaccines as alternatives to antibiotics for food producing animals. Part 1: challenges and needs. Veterinary Research, 49(1), 64. doi: 10.1186/s13567-018-0560-8

Joch, M., Kudrna, V., Hakl, J., Božik, M., Homolka, P., Illek, J., \& Výborná, A. (2019). In vitro and in vivo potential of a blend of essential oil compounds to improve rumen fermentation and performance of dairy cows. Animal Feed Science and Technology, 251, 176-186. doi: 10.1016/j. anifeedsci.2019.03.009

Kolling, G. J., Stivanin, S. C. B., Gabbi, A. M., Machado, F. S., Ferreira, A. L., Campos, M. M., \& Fischer, V. (2018). Performance and methane emissions in dairy cows fed oregano and green tea extracts as feed additives. Journal of Dairy Science, 101(5), 4221-4234. doi: 10.3168/jds.2017-13841

Kouazounde, J. B., Jin, L., Assogba, F. M., Ayedoun, M. A., Wang, Y., Beauchemin, K. A., \& Gbenou, J. D. (2015). Effects of essential oils from medicinal plants acclimated to Benin on in vitro ruminal fermentation of Andropogon gayanus grass. Journal of the Science of Food and Agriculture, 95(5), 1031-1038. doi: 10.1002/jsfa.6785

Lemus, C., Bonilla, J., Plasencia, A., \& Ly, J. (2012). Chemical characteristics of silages of mango (Mangifera indica L.) by products for animal feeding. Cuban Journal of Agricultural Science, 46(4). Recovered from https://scholar.google. com/scholar?hl=en\&as_sdt $=0 \% 2 \mathrm{C} 5 \& \mathrm{q}=\mathrm{C}$ 
hemical+characteristics+of+silages+of+ mango+\%28Mangifera+indica+L.\%29+by +products+for+animal+ feeding\&btnG =

Lynch, J. P., Prema, D., Van Hamme, J. D., Church, J. S., \& Beauchemin, K. A. (2014). Fiber degradability, chemical composition and conservation characteristics of alfalfa haylage ensiled with exogenous fibrolytic enzymes and a ferulic acid esteraseproducing inoculant. Canadian Journal of Animal Science, 94(4), 697-704. doi: 10.4141/cjas-2014-086

Macheboeuf, D., Morgavi, D. P., Papon, Y., Mousset, J. L., \& Arturo-Schaan, M. (2008). Dose-response effects of essential oils on in vitro fermentation activity of the rumen microbial population. Animal Feed Science and Technology, 145(1-4), 335-350. doi: 10.1016/j.anifeedsci.2007.05.044

Makkar H.P. (2010) In Vitro Screening of Feed Resources for Efficiency of Microbial Protein Synthesis. In: Vercoe P., Makkar H., Schlink A. (eds) In vitro screening of plant resources for extra-nutritional attributes in ruminants: nuclear and related methodologies. Springer, Dordrecht. doi: 10.1007/978-90-481-3297-3_7

Markham, R. (1942). A steam distillation apparatus suitable for micro-Kjeldahl analysis. Biochemical Journal, 36(10-12), 790-791. doi: 10.1042/bj0360790

McDonald, P., Henderson, A. R., \& Heron, S. J. E. (1991). The biochemistry of silage. Marlow, UK: Chalcombe Publications.340pp. Recovered from https://www.cabdirect. org/cabdirect/abstract/19930 759161

Mcdougall, E. I. (1948). The composition and output of sheep's saliva. Biochemical Journal, 43(1), 99-109. doi: 10.1042/ bj0430099
Moselhy, M. A., Borba, J. P., \& Borba, A. E. (2015). Improving the nutritive value, in vitro digestibility and aerobic stability of Hedychium gardnerianum silage through application of additives at ensiling time. Animal Feed Science and Technology, 206, 8-18. doi: 10.1016/j. anifeedsci.2015.05.001

Oladokun, S., \& Adewole, D. I. (2020). In ovo delivery of bioactive substances: an alternative to the use of antibiotic growth promoters in poultry production a review. Journal of Applied Poultry Research, 29(3), 744-763. doi: 10.1016/j.japr.2020.06.002

Palangi, V., \& Besharati, M. (2020). Validation of in situ disappearance curves utilizing mathematical models for incubating fish meal and cottonseed meal. Semina: Ciências Agrárias, 41(6Supl2), 3391-3396. doi: 10.5433/1679-0359.2020v41n6Supl2 p3391

Palangi, V., Taghizadeh, A., \& Sadeghzadeh, M. K. (2013). Determine of nutritive value of dried citrus pulp various using in situ and gas production techniques. Journal of Biodiversity and Environmental Sciences, 3(6), 8-16. Recovered from https://www. researchgate.net/profile/Valiollah_ Palangi2/publication/324561276_ Determine_of_nutritive_value_of_ dried_citrus_pulp_various_using_in_ situ_and_gas_production_techniques/ links/5ad59393a6fdcc293580adb9/ Determine-of-nutritive-value-of-driedcitrus-pulp-various-using-in-situ-andgas-production-techniques.pdf

Pour, H. A., Naserian, A. A., Vakili, A. R., \& Tahmasbi, A. M. (2017). Effect of essential plant oil used as an additive to alter silage fermentation in ruminant by in vitro. 
Biosciences Biotechnology Research Asia, 14(1), 145-152. doi: 10.13005/bbra/2429

Rafique, S., Hassan, S. M., Mughal, S. S., Hassan, S. K., \& Shabbir, N. (2020). Biological attributes of lemon: a review. Journal of Addiction Medicine and Therapeutic Science, 6(1), 30-34. doi: 10.17352/ 24553484.000034

Sardrodi, A. F., Soleimani, A., Kheiry, A., \& Zibareresht, R. (2017). Essential oil composition of Achillea aucheri Boiss at different growing altitudes in Damavand, Iran. Journal of Agriculture, Science and Technology, 19(2), 357-364. Recovered from http://jast.modares.ac.ir/article-237980-en.html

Sayyah, M., Moaied, S., \& Kamalinejad, M. (2005). Anticonvulsant activity of Heracleum persicum seed. Journal of Ethnopharmacology, 98(1-2), 209-211.

Sheikh, A., \& Jain, P. (2016). A thorough study of zinc ferrite nanoparticles with reference to green synthesis. International Journal of Nanomedicine and Nanosurgery, 2(3), 1-8. doi: 10.16966/2470-3206.115

Silva, V. P., Pereira, O. G., Leandro, E. S., Silva, T. C. da, Ribeiro, K. G., \& Mantovani, H. C. (2016). Effects of lactic acid bacteria with bacteriocinogenic potential on the fermentation profile and chemical composition of alfalfa silage in tropical conditions. Journal of Dairy Science, 99(3), 1895-1902. doi: 10.3168/jds.2015-9792

Simitzis, P. E., Deligeorgis, S. G., Bizelis, J. A., Dardamani, A., Theodosiou, I., \& Fegeros, K. (2008). Effect of dietary oregano oil supplementation on lamb meat characteristics. Meat Science, 79(2), 217223. doi: 10.1016/j.meatsci.2007.09.005
Triantafyllidis, V., Zotos, A., Kosma, C., \& Kokkotos, E. (2020). Environmental implications from long-term citrus cultivation and wide use of cu fungicides in mediterranean soils. Water, Air, \& Soil Pollution, 231(238), 1-17. doi: 10.1007/ s11270-020-04577-z

Turan, A., \& Önenç, S. S. (2018). Effect of cumin essential oil usage on fermentation quality, aerobic stability and in vitro digestibility of alfalfa silage. Asian-Australasian Journal of Animal Science, 31(8), 1252. doi: 10.5713/ajas.17.0834

Van Soest, P. J., Robertson, J. B., \& Lewis, B. A. (1991). Methods for dietary fiber, neutral detergent fiber, and nonstarch polysaccharides in relation to animal nutrition. Journal of Dairy Science, 74(10), 3583. doi: 10.3168/jds.S00220302(91)78551-2

Vasconcelos, N. G., Croda, J., \& Simionatto, S. (2018). Antibacterial mechanisms of cinnamon and its constituents: a review. Microbial Pathogenesis, 120, 198-203. doi: 10.1016/j.micpath.2018.04.036

Vergis, J., Gokulakrishnan, P., Agarwal, R. K., \& Kumar, A. (2015). Essential oils as natural food antimicrobial agents: a review. Critical Reviews in Food Science and Nutrition, 55(10), 1320-1323. doi: 10.1080/10408398.2012.692127

Youcef-Ettoumi, K., Zouambia, Y., \& MoulaiMostefa, N. (2020). Chemical composition, antimicrobial and antioxidant activities of Algerian Citrus sinensis essential oil extracted by hydrodistillation assisted by electromagnetic induction heating. Journal of Food Science and Technology, 1-7. doi: 10.1007/s13197-020-04808-5 